\title{
Effect of lectins on the invasion of I chthyophthirius theront to channel catfish tissue
}

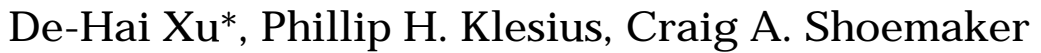 \\ United States Department of A griculture, Agricultural Research Service, Aquatic Animal Health Research Laboratory, \\ 990 Wire Road, A uburn, Alabama 36831, USA
}

\begin{abstract}
This study determined the effects of lectin binding to theronts of Ichthyophthirius multifiliis on theront immobilization, invasion, trophont development and survival in channel catfish Ictalurus punctatus excised fins in vitro. Soybean agglutinin (SBA), lentil agglutinin (LCA), gorse agglutinin (UEA-I) and wheat germ agglutinin (WGA) were used to treat theronts. Percentages of theronts immobilized by 4 lectins ranged from 12.0 to $19.4 \%$ at a concentration of $1000 \mathrm{\mu g} \mathrm{ml}^{-1}$. These lectins bound more than half of the theronts at a concentration of $50 \mu \mathrm{g} \mathrm{ml}^{-1}$. More theronts were labeled by SBA and WGA than by lectin LCA at concentrations of 50 and $100 \mu \mathrm{g} \mathrm{ml}^{-1}$, respectively. The binding of these lectins to theronts indicated that monosaccharides ( $D$-galactose, L-fucose, $\mathrm{D}$-mannose and D-glucose) and amino sugar derivatives ( $\mathrm{N}$-acetylgalactosamine and $\mathrm{N}$-acetylglucosamine) were present on the surface of theronts. Invasion was reduced significantly for theronts treated with LCA, UEA-I and WGA. No difference in invasion was found between control and SBA bound theronts $(p>0.05)$. The binding of lectin LCA, UEA-I and WGA to theronts significantly reduced the development of trophonts $(p<0.05)$. The mean volumes of trophonts labeled with these 3 lectins were smaller than volumes in control trophonts from 8 to $48 \mathrm{~h}$ after exposure. Survival was lower in trophonts labeled with lectins than in control trophonts at $48 \mathrm{~h}$ after exposure.
\end{abstract}

KEY WORDS: Lectins · Ichthyophthirius · Immobilization · Invasion · Development · Tissue

Resale or republication not permitted without written consent of the publisher

\section{INTRODUCTION}

Ichthyophthirius multifiliis is one of the most virulent ciliated parasites of freshwater fish and causes serious problems in intensively cultured and ornamental fish (Hines \& Spira 1973, Nigrelli et al. 1976). The life stages of the parasite include a reproductive tomont, an infective theront, and a parasitic trophont (M acLennan 1935, McCartney et al. 1985, Dickerson \& Dawe 1995). A reproductive tomont undergoes multiple divisions to produce 100 to 1000 tomites in each cyst. The invading theronts differentiate from the tomite, swim actively in water and seek a fish to parasitize. Theronts penetrate the epithelium of fin, gill and skin of fish and become feeding trophonts. After leaving the host at maturation, trophonts form reproductive tomonts on an

*E-mail: dxu@ars.usda.gov appropriate surface by secreting a cyst wall (MacLennan 1935, McCartney et al. 1985).

Lectins are sugar-binding proteins that are mainly of plant origin, but also occur in animals, fungi, bacteria and viruses. These proteins, which bind specifically to carbohydrate residues (Doyle 1994), are frequently used in parasitological research to detect pathogenic parasites (de M ateo et al. 1997), differentiate between parasite species (Munoz et al. 1999), define developmental stages (Dawidowicz et al. 1975, Wilson \& Pearson 1984, Grogl et al. 1987), and reveal differences in avirulent and virulent strains of parasites (Ayesta et al. 1985, Sacks et al. 1985, Vommaro et al. 1997, Feng $\&$ Woo 1998). Lectins have also been used for characterization of glycoconjugates and tests of viability of parasite isolation (Driscoll \& Hufnagel 1999, Fuchs et al. 1999).

Natural lectins have been reported to occur in the skin mucus of different species of fish (Kamiya \& 
Shimizu 1980, Kamiya et al. 1988, Toda et al. 1996). Lectins in windowpane flounder Lophopsetta maculata (Kamiya \& Shimizu 1980) and conger eel Conger myriaster (Kamiya et al. 1988) have been shown to agglutinate microorganisms. Animal lectins have been categorized into C-type and S-type major lectin families, according to the sequence homology, the carbohydrate recognition domains, and calcium ion dependency of the activity (Drickamer 1988). The skin mucus of the kingklip Genypterud capensis was found to contain a C-type lectin with mitogenic activities for $T$ lymphocytes but not for B lymphocytes (Toda et al. 1996).

Carbohydrates have been reported in the surface coat of parasites, such as Cryptobia spp. (Vommaro et at. 1997, Feng \& Woo 1998), Entamoeba invadens (Ribeiro et al. 1997), Glugea plecoglossi (Kim et al. 1999), Leishmania spp. (Grogl et al. 1987, J affe \& M cMahon-Pratt 1988), Sphaerospora sp. (de Mateo et al. 1997) and Trichomonas vaginalis (Mirhaghani \& Warton 1998), where they are thought to be involved in recognition of the host and attachment to host cells. Treatment with lectins to block sugar residues on the surface of parasites affected the adhesion of the parasite to the target host cells (Bray 1983, Mirhaghani \& Warton 1998, Kim et al. 1999).

M ost studies on theront invasion and trophont development have used histological techniques (Ewing et al. 1985, Ewing \& Kocan 1986), fixed trophonts (MacLennan 1942) or tissue wet mounts (Hines \& Spira 1973). These methods, however, were not suitable for continuous observation of the invasion, development and survival of the same population of theronts and trophonts. In this study, we used an in vitro culture method ( $\mathrm{Xu}$ et al. 2000) that makes it possible to observe theronts and trophonts continuously after treatment with lectins.

In a previous study on the early development of Ichthyophthirius in channel catfish Ictalurus punctatus tissues in vitro (Xu et al. 2000), we noted that some theronts left catfish tissues if they did not find suitable sites to invade after initial contact with host tissues. This indicated that the surface of the theront played an important role in host invasion. Although carbohydrate-lectin interactions serve as a basis for recognition and attachment for some parasites (Bray 1983, Sharon 1984, Mirhaghani \& Warton 1998), little is known of the interaction between lectins and Ichthyophthirius theronts. In the present study, we treated theronts with the lectins soybean agglutinin (SBA), lentil agglutinin (LCA), gorse agglutinin (UEA-I) and wheat germ agglutinin (WGA), and examined the effect of lectin treatment on theront penetration of host epidermis, trophont development and survival in channel catfish excised fins in vitro.

\section{METHODS}

Fingerling channel catfish, reared at the United States Department of Agriculture, Aquatic Animal Health Research Laboratory, Auburn, Alabama, were used as host fish and maintained in tanks for more than $8 \mathrm{mo}$ in flowing dechlorinated fresh water at 20 to $25^{\circ} \mathrm{C}$. The fish were $11.8 \pm 0.7 \mathrm{~cm}$ (mean $\pm \mathrm{SD}$ ) in length and $10.5 \pm 1.4 \mathrm{~g}$ in weight.

Ichthyophthirius multifiliis was isolated from a black tetra, Gymnocorymbus ternetzi (Boulenger), obtained from a local pet shop and maintained by serial transmission on channel catfish held in 50 I glass aquaria equipped with undergravel filters at $22^{\circ} \mathrm{C}$. Infective theronts were prepared for this experiment as previously described (Xu et al. 2000). Briefly, a fish heavily infected with maturing trophonts ( $6 \mathrm{~d}$ after infection) was rinsed in tank water and the skin was gently scraped to dislodge the parasites. Isolated trophonts were placed in Petri dishes with sterile distilled water and incubated for $24 \mathrm{~h}$ at $23^{\circ} \mathrm{C}$. Theronts were used within $5 \mathrm{~h}$ excystment for tissue infection.

Lectin mediated immobilization. An immobilization assay was performed in 96-well microtiter plates. Highly purified lectins were adjusted to concentrations of $62.5,125,250,500$ and $1000 \mathrm{mg} \mathrm{ml}^{-1}$ with phosphate buffered saline (PBS, pH 7.2). The specificities of lectins used in this experiment are listed in Table 1. A $200 \mu \mathrm{l}$ aliquot of lectin solution and 300 theronts were added to each well. Theronts were enumerated in three $20 \mu \mathrm{l}$ samples of suspension with the aid of a Sedgewick-Rafter cell (VWR Scientific Products, Atlanta, GA, USA) and the theront concentration was calculated as numbers of theronts $\mathrm{ml}^{-1}$. The mixtures of lectin and theront were incubated at $22^{\circ} \mathrm{C}$ for $2 \mathrm{~h}$. Blank wells without lectins served as control. Immobilized theronts were counted under an inverted microscope and theronts that lost forward mobility were considered as immobilized theronts.

Table 1. Lectins used in this study and their saccharide specificities

\begin{tabular}{|lll|}
\hline Symbol & Lectin (source) & Saccharide specificity \\
\hline SBA & $\begin{array}{l}\text { Soybean agglutinin } \\
\text { (Glycine max) }\end{array}$ & $\begin{array}{l}\text { N-acetylgalactosamine, } \\
\text { D-galactose }\end{array}$ \\
LCA & $\begin{array}{l}\text { Lentil agglutinin } \\
\text { (Lens culinaris) }\end{array}$ & $\begin{array}{l}\text { D-mannose and } \\
\text { D-glucose }\end{array}$ \\
UEA-I & $\begin{array}{l}\text { Gorse agglutinin } \\
\text { (Ulex europaeus) }\end{array}$ & L-fucose \\
WGA & $\begin{array}{l}\text { Wheat germ agglutinin } \\
\text { (Triticum vulgaris) }\end{array}$ & N-acetylglucosamine \\
& Sigma Chemical Co., St. Louis, MO, USA \\
\hline
\end{tabular}


Lectin binding assay. Theronts were fixed in $1 \%$ formalin for $1 \mathrm{~h}$, rinsed in PBS and then incubated in 1 of the fluorescent isothiocyanate (FITC)-conjugated lectins (Sigma, St. Louis, M O, USA) for $1 \mathrm{~h}$ in the dark at room temperature. The concentrations used for each lectin were $6.5,12.5,25,50$ and $100 \mu \mathrm{g} \mathrm{ml}^{-1}$. Theronts without FITC-conjugated lectins were used as a control for each lectin assay. Excess lectin was removed by washing twice with PBS and the samples were analyzed using a Coulter Epics flow cytometer (Coulter Corporation, Miami, FL, USA) equipped with a $15 \mathrm{~mW}$ argon ion laser operating at $488 \mathrm{~nm}$.

Theront attachment and trophont development. The supplemented Medium 199 was made by diluting Medium 199 (Sigma) with sterile distilled water (1:1) and then supplemented with $2.5 \%$ fetal bovine serum (Sigma), $50 \mathrm{IU} \mathrm{ml}^{-1}$ penicillin and $50 \mathrm{\mu g} \mathrm{ml}^{-1}$ streptomycin (Sigma). Caudal and anal fins were collected from catfish fingerlings naive to Ichthyophthirius multifiliis. Before dissection, fish were kept for 15 min in sterile water to flush loosely bound bacteria. Fish were killed by pithing the brain and fins were dissected with sterile instruments. After washing 3 times each in sterile distilled water and M edium 199, fins were cut separately into $5 \times 5 \mathrm{~mm}$ pieces in a Petri dish with M edium 199. Two pieces of fin were inoculated in 1 well of a 24-well plate (Costar, Cambridge, MA, USA). After addition of the tissue, $500 \mu \mathrm{l}$ supplemented Medium 199 was added to each well. Duplicated wells were used in replicated trials $(n=4)$.

Theronts were incubated with each purified lectin at a concentration of $200 \mu \mathrm{g} \mathrm{ml}^{-1}$ for $30 \mathrm{~min}$ and then added to each well at 300 theronts well ${ }^{-1}$ within $15 \mathrm{~min}$ of tissue collection. Theront invasion and trophont development were observed under an inverted microscope at 1, 4, 8, 24 and $48 \mathrm{~h}$ after exposure. At each time interval for each well, 50 trophonts in tissues were counted randomly to determine percentage invasion and survival. Theronts having fusiform shape and moving on the tissue surface were considered uninvasive theronts. Invasive theronts were those that invaded fish fins, rounded to oval in shape and rotated within tissue spaces. Percentage invasion was the number of invasive theronts divided by the number of total theronts counted in tissues. Trophonts without rotation and non-beating cilia were considered dead. Ten trophonts were measured in each well for their size in diameter with a calibrated ocular micrometer, and volume was calculated with the following formula: volume $=\pi \times D^{3} / 6$, where $D$ is diameter.

Data analysis. The trophont volume, and percentage invasion and survival for theronts treated with different lectins were analyzed with Duncan's multiple range test (SAS Institute Inc, Cary, NC, USA). Probabilities of 0.05 or less were considered significant.

\section{RESULTS}

\section{Lectin-binding assay}

A small portion of theronts was labeled by lectins at a concentration of $25 \mathrm{\mu g} \mathrm{ml}^{-1}$ or less (Fig. 1). The number of theronts labeled by lectins increased significantly with higher lectin concentrations. More than $50 \%$ of theronts were labeled by 4 lectins at a concentration of $50 \mu \mathrm{g} \mathrm{ml}^{-1}$. Theronts labeled by SBA and WGA were 25 and $30 \%$ more than those labeled by lectin LCA at a concentration of 50 and $100 \mu \mathrm{g} \mathrm{m}{ }^{-1}$, respectively. Binding of 4 lectins to theronts indicated that the monosaccharides D-galactose, L-fucose, Dmannose and D-glucose, and the amino sugar derivatives $\mathrm{N}$-acetylgalactosamine and $\mathrm{N}$-acetylglucosamine were present on the surface of theronts.

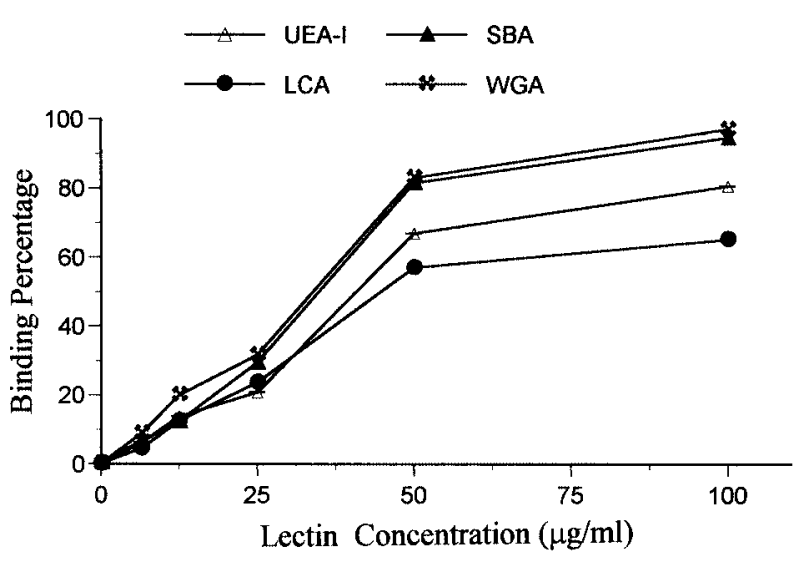

Fig.1. Percentage of theronts fluorescing after treatment with fluorescent isothiocyanate conjugated lectins at various concentrations $\left(\mu \mathrm{g} \mathrm{ml}^{-1}\right)$. Samples were read using a Coulter Epics flow cytometer equipped with a $15 \mathrm{~mW}$ argon ion laser operating at $488 \mathrm{~nm}$. LCA: lentil agglutinin; SBA: soybean agglutinin; UEA-I: gorse agglutinin; WGA: wheat germ agglutinin

\section{Lectin-mediated immobilization}

Theronts were partially immobilized by 4 lectins at a concentration of 500 to $1000 \mathrm{\mu g} \mathrm{ml}^{-1}$. Some theronts lost forward mobility and failed to show normal swimming behavior. Immobilized theronts remained alive for up to $4 \mathrm{~h}$ and their cilia were observed to continue beating. Percentages of theronts immobilized by lectin SBA, LCA, UEA-I and WGA were 12.0, 12.5, 14.7 and $19.4 \%$ at a concentration $1000 \mu \mathrm{g} \mathrm{ml}^{-1}$, and 5.7, 11.1, 2.9 and $12.3 \%$ at $500 \mathrm{\mu g} \mathrm{ml}^{-1}$, respectively. No immobilization was observed with lectins at a concentration of $250 \mathrm{\mu g} \mathrm{ml}^{-1}$ or lower. 


\section{Theront invasion, trophont development and survival}

When lectin treated theronts were added to excised tissues, the percentage invasion was reduced significantly for lectin LCA, UEA-I and WGA (Table 2). No difference in invasion was found between control and SBA bound theronts $(p>0.05)$.

Unlabeled theronts and theronts labeled with lectin SBA grew into trophonts with similar volume at 8 and $24 \mathrm{~h}$ after exposure (Table 3). The binding of lectin LCA, UEA-I and WGA to theronts significantly reduced the size of trophonts $(p<0.05)$. The mean vol-

Table 2. Effect of lectin binding on theront invasion (\%) in excised catfish fins at different times. Values are mean $\pm S D$ $(n=4)$. Within a column, means followed by the same lower case letter are not significantly different $(p>0.05)$. See Table 1 for abbreviations

\begin{tabular}{|c|c|c|c|}
\hline \multirow[t]{2}{*}{ Lectin } & \multicolumn{3}{|c|}{ Percent of invasive theronts } \\
\hline & $1 \mathrm{~h}$ & $4 \mathrm{~h}$ & $8 \mathrm{~h}$ \\
\hline Control & $89.2 \pm 13.1^{\mathrm{a}}$ & $93.2 \pm 8.9^{a}$ & $98.7 \pm 7.3^{a}$ \\
\hline SBA & $87.0 \pm 1.5^{a}$ & $96.4 \pm 1.9^{a}$ & $99.3 \pm 0.9^{a}$ \\
\hline LCA & $52.0 \pm 12.4^{c}$ & $81.2 \pm 2.0^{b}$ & $81.9 \pm 13.0^{b}$ \\
\hline UEA-I & $68.1 \pm 4.6^{\mathrm{b}}$ & $77.5 \pm 4.5^{b}$ & $74.4 \pm 9.9^{b}$ \\
\hline WGA & $50.8 \pm 24.2^{c}$ & $65.7 \pm 8.4^{c}$ & $73.8 \pm 23.7^{b}$ \\
\hline
\end{tabular}

Table 3. Effect of lectin binding on trophont volume $\left(\mathrm{m}^{3}\right)$ in excised catfish fins at different times. Values are mean $\pm S D$ $(n=40)$. Within a column, means followed by the same lower case letter are not significantly different $(p>0.05)$. See Table 1 for abbreviations

\begin{tabular}{|lccc|}
\hline \multirow{2}{*}{ Lectin } & \multicolumn{4}{c|}{ Mean volume in $\mu m^{3} \pm S D$} \\
& $8 \mathrm{~h}$ & $24 \mathrm{~h}$ & $48 \mathrm{~h}$ \\
\hline Control & $17511 \pm 5032^{\mathrm{a}}$ & $23032 \pm 6692^{\mathrm{a}}$ & $29129 \pm 9400^{\mathrm{a}}$ \\
SBA & $18221 \pm 6312^{\mathrm{a}}$ & $22783 \pm 6609^{\mathrm{a}}$ & $25670 \pm 7218^{\mathrm{b}}$ \\
LCA & $12689 \pm 2059^{\mathrm{b}}$ & $15580 \pm 3100^{\mathrm{b}}$ & $20741 \pm 6589^{\mathrm{c}}$ \\
UEA-I & $14466 \pm 4720^{\mathrm{b}}$ & $18362 \pm 6258^{\mathrm{b}}$ & $19648 \pm 2279^{\mathrm{c}}$ \\
WGA & $15141 \pm 5033^{\mathrm{b}}$ & $16726 \pm 6258^{\mathrm{b}}$ & $22080 \pm 9129^{\mathrm{c}}$ \\
\hline
\end{tabular}

Table 4. Effect of lectin binding on trophont survival (\%) in excised catfish fins at different times. Values are mean \pm SD $(n=4)$. Within a column, means followed by the same lower case letter are not significantly different $(p>0.05)$. See Table 1 for abbrevations

\begin{tabular}{|lccc|}
\hline \multirow{2}{*}{ Lectin } & \multicolumn{3}{c|}{ Mean survival (\%) \pm SD } \\
& $8 \mathrm{~h}$ & $24 \mathrm{~h}$ & $48 \mathrm{~h}$ \\
\hline Control & $99.5 \pm 1.7^{\mathrm{a}}$ & $88.6 \pm 9.3^{\mathrm{a}}$ & $34.4 \pm 9.1^{\mathrm{a}}$ \\
SBA & $100 \pm 0.0^{\mathrm{a}}$ & $90.0 \pm 1.9^{\mathrm{a}}$ & $29.8 \pm 2.9^{\mathrm{b}}$ \\
LCA & $100 \pm 0.0^{\mathrm{a}}$ & $84.9 \pm 13.4^{\mathrm{a}}$ & $11.3 \pm 2.7^{\mathrm{c}}$ \\
UEA-I & $100 \pm 0.0^{\mathrm{a}}$ & $78.0 \pm 2.3^{\mathrm{b}}$ & $23.5 \pm 1.0^{\mathrm{b}}$ \\
WGA & $98.5 \pm 2.7^{\mathrm{a}}$ & $77.8 \pm 2.9^{\mathrm{b}}$ & $29.5 \pm 1.7^{\mathrm{b}}$ \\
\hline
\end{tabular}

umes of trophonts labeled with these 3 lectins were only $80.2,73.3$ and $71.5 \%$ of trophont volumes from unlabeled theronts at 8,24 and $48 \mathrm{~h}$, respectively. No difference was found in size of trophonts among theronts labeled with lectin LCA, UEA-I and WGA $(p>0.05)$.

Survival was lower in trophonts labeled with lectins than in unlabeled trophonts at $48 \mathrm{~h}$ after exposure $(\mathrm{p}<$ $0.05)$. No difference in mean survival $(p>0.05)$ was found in theronts labeled with lectin SBA, UEA-I and WGA (Table 4).

\section{DISC USSION}

Theronts were immobilized only in the high concentrations of lectins in this study. Binding of lectins to the theront surface added a burden to the parasite and decreased the mobility of theronts. The ability of lectins to immobilize theronts indicated that there might be an interaction between lectins and theront surface carbohydrates. However, the burden generated by the lectin bound to theront surface was not large enough to immobilize all of the theronts. It is not clear whether carbohydrates change during the development stages and in different strains of Ichthyophthirius, although some variation has been reported in other parasites. In studies of virulent and an avirulent strain of Cryptobia spp., Feng \& Woo (1998) found that the attenuated strain developed more surface carbohydrates than the virulent strain.

Lectins are multivalent with respect to sugar binding and can readily form bridges between cells (Sharon 1984). Linking several or more cells may create aggregates, and agglutination has been reported in protozoans treated with various lectins (Ribeiro et al. 1997, Feng \& Woo 1998). No clumps and aggregates of theronts were observed in lectin solutions in this study even though some theronts were immobilized. This may be attributed to the large size of theronts and their strong swimming power.

Suzuki \& Kaneko (1986) revealed that the mucus lectin in eels was secreted from the club cells in skin with molecular weight 370000 . The mucus lectin was different from the immunoglobulin in eels, which was produced mainly by lymphocytes with molecular weight 140000 (McArther 1978). Although mucus lectins in fish are known to agglutinate microorganisms (Kamiya \& Shimizu 1980, Kamiya et al. 1988), it is not clear whether these mucus lectins can immobilize theronts. Antibodies from both serum and mucus of Ichthyophthirius immune fish cause strong immobilization of theronts (Hines \& Spira 1974, Wahli \& M eier 1985, Clark et al. 1987). If the mucus lectins can immobilize theronts, it may bring an enhanced effect on 
theront immobilization by both antibodies and mucus lectins.

Direct analysis of individual cells with glycoconjugates on the cell surface by flow cytometry gives invaluable information on the distribution, dynamics and biological roles of glycoconjugates. Some lectins with multiple binding sites can agglutinate cells and cause problems for the application of lectins in flow cytometry (Kaku \& Shibuya 1998). Since single cell suspensions are required for flow cytometry, to avoid stacking problems and for accurate measurement, lectins should be used in the concentration range in which agglutination does not occur. In this experiment, 6.5 to $100 \mathrm{\mu g} \mathrm{ml}^{-1}$ lectin solution was used since it was found that all 4 lectins did not immobilize and agglutinate theronts at concentrations of $250 \mu \mathrm{g} \mathrm{ml}^{-1}$ or less.

The use of flow cytometric technique combined with fluorescent labels allowed us to quantify large number of theronts labeled with lectins. Two main tools were used to detect fluorescent labels on the surface of parasites: the fluorescent microscope and flow cytometer (J acobson 1994). A fluorescent microscope can be useful in detecting and visualizing the lectin binding region. A flow cytometer with fluorescent detector, however, is more powerful in revealing lectin labeling on the surface of cells. In this experiment, we used the flow cytometer to detect as little as $6.5 \mu \mathrm{g} \mathrm{ml}^{-1}$ of FITC labeled lectins on theront surface.

All 4 lectins, SBA, LCA, UEA-I and WGA, bound to the surface of theronts in this study and were specific to the monosaccharides D-galactose, L-fucose, D-mannose and D-glucose, and the amino sugar derivatives $\mathrm{N}$-acetylgalactosamine and $\mathrm{N}$-acetylglucosamine. It has been reported in other studies that sugars and amino derivatives similar to those in our study are present on the surface of protozoans, such as various Leishmania spp. (J acobson 1994) and Entamoeba invadens (Ribeiro et al. 1997).

Carbohydrate-lectin interactions may occur in 3 different ways (Sharon 1984). In our theront-host tissue model, the following interactions may occur: (1) between sugars on the surface of theronts and lectins on the surface of host tissues; (2) between lectins on the surface of theronts and sugars on the surface of host tissues; and (3) by extracellular lectins that form bridges between sugars on both theronts and host tissues. In this study, we found that lectins LCA, UEA-I and WGA significantly reduced the percentage of invasive theronts to the excised tissue in vitro. The treatment of theronts with lectins WGA, UEA-I and LCA blocked $\mathrm{N}$-acetylglucosamine, L-fucose and $\mathrm{D}$ mannose or D-glucose, which serve as carbohydrate receptors. Lectins have been reported to influence the invasion of protozoan parasites to their host. Bray (1983) found that promastigotes of Leishmania mexi- cana mexicana treated with lectin Con $\mathrm{A}$ and phytohemagglutinin at $4^{\circ} \mathrm{C}$ greatly reduced the invasion to macrophages in vitro. Treatment of macrophages with lectin WGA at $36^{\circ} \mathrm{C}$ also reduced parasite attachment. This suggested that the $\mathrm{N}$-acetylglucosamine moiety may serve as part of the receptor. Kim et al. (1999) reported that the treatment of microsporidian Glugea plecoglossi with lectins significantly reduced phagocytosis by head kidney macrophages of ayu Plecoglossus altivelis.

In summary, carbohydrate receptors were present on the surface of theronts, and the treatment of theronts with lectins WGA, UEA-I and LCA reduced the invasion of theronts to the excised tissue in vitro.

Acknowledgements. The authors would like to thank Drs Byron L. Blagburn, Harry W. Dickerson and J ohn M. Grizzle for critically reviewing and Ms Pam Awbrey for editing the manuscript.

\section{LITERATURE CITED}

Ayesta C, Arguella C, Hernandez AG (1985) Leishmania braziliensis: cell surface differences in promastigotes of pathogenic and nonpathogenic strains. Exp Parasitol 59: 185-191

Bray RS (1983) Leishmania mexicana mexicana: attachment and uptake of promastigotes to and by macrophages in vitro. J Protozool 30:314-322

Clark TG, Dickerson HW, Gratzek JB, Findly RC (1987) in vitro response of Ichthyophthirius multifiliis to sera from immune channel catfish. J Fish Biol 31(Suppl A):203-208

Dawidowicz K, Hernandez AG, Infante RB, Convit J (1975) The surface membrane of Leishmania. I. The effects of lectins on different stages of Leishmania braziliensis. J Parasitol 61:950-953

de Mateo M M, Bovo G, Comuzzi M, Adams A (1997) Lectin histochemical studies on Sphaerospora sp. (Myxosporea) from Italian brown trout, Salmo trutta L. J Fish Dis 20: 51-58

Dickerson HW, Dawe DL (1995) Ichthyophthirius multifiliis and Crypotocaryon irritans (Phylum Ciliophora). In: Woo P (ed) Fish diseases and disorders, Vol. 1. CAB International, Wallingford, $p$ 181-227

Drickamer K (1988) Two distinct classes of carbohydraterecognition domains in animal lectins. J Biol Chem 263: 9557-9560

Doyle RJ (1994) Introduction to lectins and their interactions with microorganisms. In: Doyle RJ , Slifkin M (eds) Lectinmicroorganism interactions. Marcel Dekker, Inc, New York, p 1-65

Driscoll C, Hufnagel LA (1999) Affinity-purification of concanavalin A-binding ciliary glycoconjugates of starved and feeding Tetrahymena thermophila. J Eukaryot M icrobiol 46:142-146

Ewing M S, Kocan KM (1986) Ichthyophthirius multifiliis (Ciliophora) development in gill epithelium. J Protozool 33: 369-374

Ewing MS, Kocan KM, Ewing SA (1985) Ichthyophthirius multifiliis (Ciliophora) invasion of gill epithelium. J Protozool 32:305-310

Feng S, Woo PTK (1998) Identification of carbohydrates on the surface membrane of pathogenic and nonpathogenic 
piscine haemoflagellates, Cryptobia salmositica, C. bullocki and C. catostomi (Kinetoplastida). Dis Aquat Org 32: 201-209

Fuchs N, Ingold K, Sonda S, Butikofer P, Hemphill A (1999) Detection of surface-associated and intracellular glycoconjugates and glycoproteins in Neospora caninum tachyzoites. Int J Parasitol 29:1597-1611

Grogl M, Franke ED, McGreevy PB, Kuhn RE (1987) Leishmania braziliensis protein, carbohydrate and antigen differences between log phase and stationary phase promastigotes in vitro. Exp Parasitol 83:352-359

Hines RS, Spira DT (1973) Ichthyophthirius multifiliis (Fouquet) in the mirror carp, Cyprinus carpio L. I. Course of infection. J Fish Biol 5:385-392

Hines RS, Spira DT (1974) Ichthyophthiriasis in the mirror carp Cyprinus carpio (L.) V. Acquired immunity. J Fish Biol 6:373-378

J acobson RL (1994) Lectin-Leishmania interaction. In: Doyle RJ, Slifkin $M$ (eds) Lectin-microorganism interactions. Marcel Dekker, Inc., New York, p 191-223

J affe CL, M CM ahon-Pratt D (1988) The identification of membrane glycoconjugates in Leishmania species. J Parasitol 74:548-561

Kaku H, Shibuya N (1998) Use of monomeric, monovalent lectin derivatives for flow cytometric analysis of cell surface glycoconjugates. In: Rhodes J M, Miton JD (eds) Lectin methods and protocols. Humana Press Inc, Totowa, New J ersey, p 301-306

Kamiya H, Shimizu Y (1980) Marine biopolymers with cell specificity II. Purification and characterization of agglutinins from mucus of windowpane flounder Lophopsetta maculata. Biochim Biophys Acta 622:171-178

Kamiya H, M uramoto K, Goto R (1988) Purification and properties of agglutinins from conger eel, Conger myriaster (Brevoort), skin mucus. Dev Comp Immunol 12:309-331

Kim JH, Ogawa K, Wakabayashi H (1999) Lectin-reactive components of the microsporidian Glugea plecoglossi and their relation to spore phagocytosis by head kidney macrophages of ayu Pleoglossus altivelis. Dis Aquat Org 39:59-63

MacLennan RF (1935) Observations on the life cycle of Ichthyophthirius, a ciliate parasitic on fish. Northwest Sci 9:12-14

MacLennan RF (1942) Growth in the ciliate Ichthyophthirius II. Volume. J Exp Zool 91:1-13

McArther CP (1978) Homoral antibody production by New Zealand eels, against the intestinal treatode Telogaster

Editorial responsibility: Wolfgang Körting, Hannover, Germany opisthorchis Macfarlane, 1945. J Fish Dis 1:377-381

McCartney J B, Fortner GW, Hansen MF (1985) Scanning electron microscopic studies of the life cycle of Ichthyophthirius multifiliis. J Parasitol 71:218-226

Mirhaghani A, Warton A (1998) Involvement of Trichomonas vaginalis surfaces-associated glycoconjugates in the parasite/target cell interaction. A quantitative electron microscopy study. Parasitol Res 84:374-381

M unoz P, Palenzuela O, Alvarez-Pellitero P, Sita-Bobadilla A (1999) Comparative studies on carbohydrates of several parasites of fish using lectin histochemical methods. Folia Parasitol 46:241-247

Nigrelli RF, Pokorny KS, Ruggieri GD (1976) Notes on Ichthyophthirius multifiliis, a ciliate parasitic on freshwater fishes, with some remarks on possible physiological races and species. Trans Am M icrosc Soc 95:607-613

Ribeiro S, de Araujo Soares RM, Sales A Iviano C, Da Silva EF, De Souza W, Angluster J (1997) Cell-surface carbohydrates of Entamoeba invadens. Parasitol Res 83:801-805

Sacks DL, Hieny S, Sher A (1985) Identification of cell surface carbohydrate and antigenic changes between non-infective and infective developmental stages of Leishmania major promastigotes. J Immunol 135:564-569

Sharon N (1984) Surface carbohydrates and surface lectins are recognition determinants in phagocytosis. Immunol Today 5:143-147

Suzuki Y, Kaneko T (1986) Demonstration of the mucus hemagglutinin in the club cells of eel skin. Dev Comp Immunol 10:509-518

Toda M, Goto R, M uramoto K, Kamiya H (1996) Characterization of the lectin from the skin mucus of the kingklip Genypterus capensis. Fish Sci 62:138-141

Vommaro RC, Attias M, Silva Filho FC, Woo PTK, De Souza W (1997) Surface charge and surface carbohydrates of Cryptobia salmositica virulent and avirulent forms and of $C$. bullocki (Kinetoplastida: Cryptobiidae). Parasitol Res 76: 294-300

Wahli T, M eier W (1985) Ichthyophthiriasis in trout: investigation of natural defense mechanisms. In: Ellis AE (ed) Fish and shellfish pathology. Academic Press, London, p 347-352

Wilson ME, Pearson RD (1984) Stage-specific variations in lectin binding to Leishmania donovani. Infect Immun 46: 128-134

Xu DH, Klesius PH, Shoemaker CA, Evans JJ ( 2000) The early development of Ichthyophthirius multifiliis in channel catfish in vitro. J Aquat Anim Health 12:290-296

Submitted: N ovember 3, 2000; Accepted: February 27, 2001 Proofs received from author(s): M ay 24, 2001 